\title{
Neurocutaneous melanosis: a rare manifestation of congenital melanocytic nevus
}

\author{
Joshua H Lee, ${ }^{1}$ Andrew B Jackson, ${ }^{1}$ Yawen Ren, ${ }^{1}$ Kavya Indira Rao ${ }^{2}$
}

'Paediatrics, University of Texas Health Science Center at Houston, Houston, Texas, USA ${ }^{2}$ Child Neurology, Children's Memorial Hermann Hospital, Houston, Texas, USA

\section{Correspondence to Dr Kavya Indira Rao, kira04@gmail.com}

Accepted 15 August 2019

\section{DESCRIPTION}

A newborn baby presented with a large melanocytic nevus covering the suprapubic, inguinal and thigh regions as well as numerous satellite lesions on the torso, shoulders and legs (figure 1). MRI of the brain demonstrated areas of T1 and T2 hyperintensity within the bilateral hippocampi, choroid plexus and left cerebellum (figure 2). MRI of the spine revealed a small $\mathrm{T} 1$ hyperintense nodule along the cauda equina at the L2 level (figure 2). Lumbar puncture with cytology was negative for malignancy. Together with the multiple melanocytic nevi, these central nervous system (CNS) lesions are consistent with neurocutaneous melanosis (NCM). The patient demonstrated no focal neurologic deficits in infancy and was discharged at 9 days of life. The patient is currently meeting developmental milestones for age, but he developed global hypertonia by 4 months of life. He is being followed on

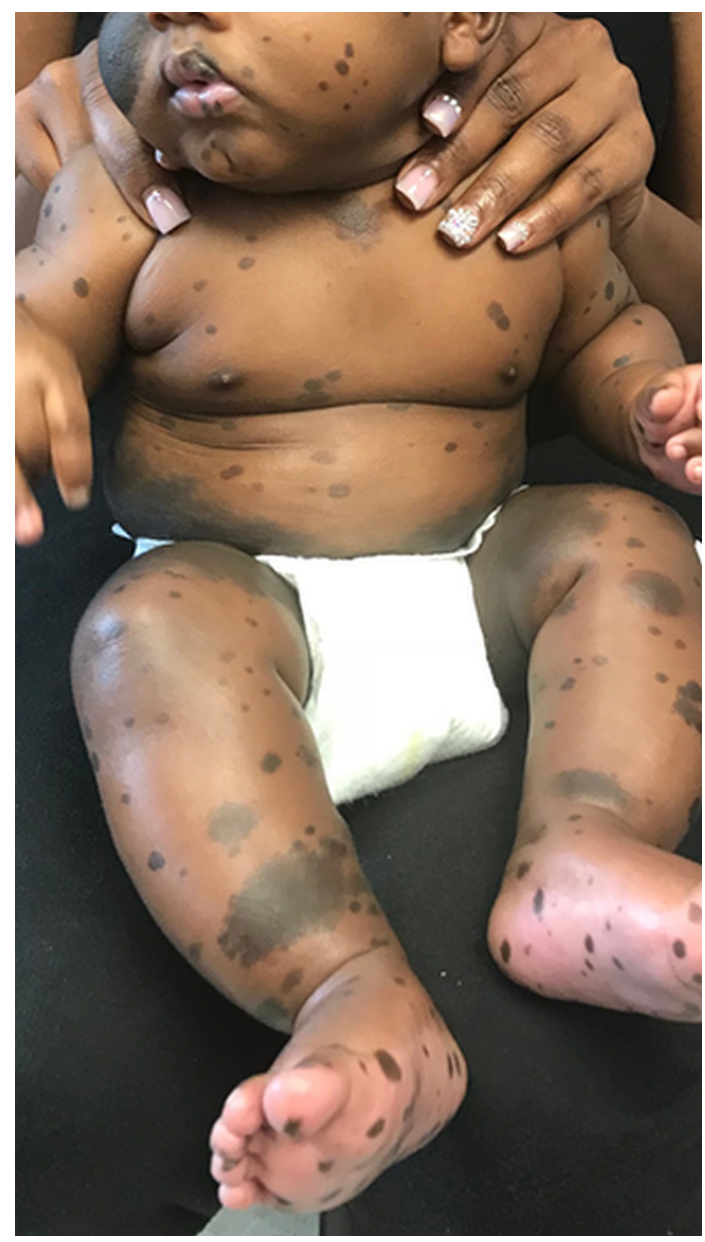

Figure 1 Clinical findings on our patient, anterior view.

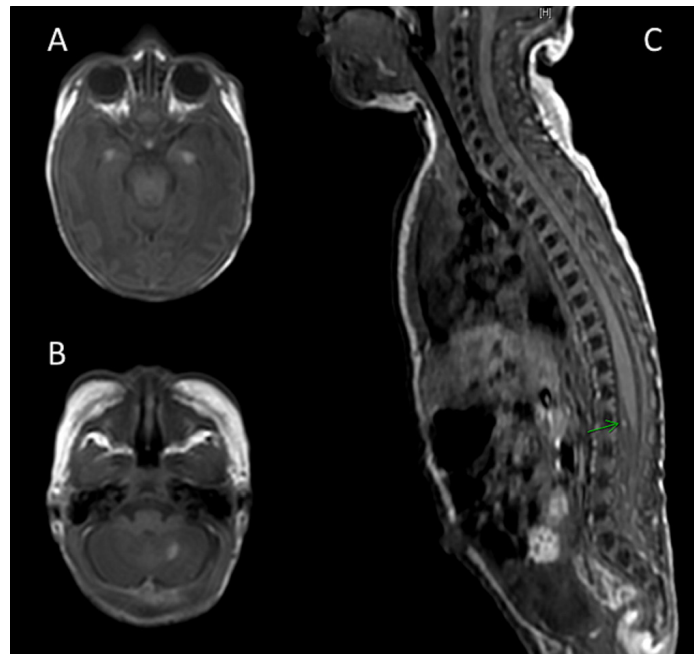

Figure 2 T1-weighted precontrast MRI of the brain demonstrates nodules in bilateral hippocampal formations (A) and left cerebellum (B). T1-weighted precontrast MRI of the spine demonstrates a hyperintense nodule at $\mathrm{L} 2(\mathrm{C})$.

an outpatient basis by paediatric neurology and paediatric dermatology, and he is now 18 months old and meeting developmental milestones for age.

NCM should be suspected when a patient presents with large congenital melanocytic nevus (CMN) or $\mathrm{CMN}$ with multiple satellite nevi. Large CMN are those over $40 \mathrm{~cm}^{2}$ in area. Large CMN having more satellite lesions are correlated with higher risk of NCM. ${ }^{1} \mathrm{NCM}$ is diagnosed when there are lesions anywhere in the central nervous system. The diagnostic test of choice is MRI with gadolinium contrast of the brain and spine. Typical findings include hyperintense areas on the temporal lobes on T1-weighted imaging as well as leptomeningeal enhancement. ${ }^{2}$ Melanomas can also be visualised in the CNS. NCM has a poor prognosis and majority of the patients die

\section{Patient's perspective}

Sometimes, people at the park or at the playground interrupt our family time to ask us if he is contagious. I am working on making business cards explaining his diagnosis to hand out, so others can learn about him without me having to explain it to them. It is helpful to follow nevus groups on social media. Connecting with other families and hearing their experiences has helped a lot. Sometimes other people in the community with nevi see him and stop to talk to us. One of them told us, 'He's going to be special' (statements by patient's mother). 


\section{Learning points}

MRI of both the brain and the spine are recommended for patients with large congenital melanocytic nevus (CMN) or CMN with satellite lesions.

- CNS lesions can be found commonly in the mesial anterior temporal lobes, cerebellum and leptomeninges. Common clinical findings include seizures, hydrocephalus and lethargy.

- Treatment is symptomatic and surgical resection of melanocytic nevi is not usually recommended.

within 3 years of birth. ${ }^{3}$ Therefore, a timely diagnosis is pertinent to ensure maximal quality of life in the remaining time.

Acknowledgements The authors would like to thank Dr lan J Butler for his assistance in preparing this manuscript. The authors would like to thank the patient and the patient's family for allowing their information to be shared.
Contributors $A B J, J H L$ and YR summarised the case and researched appropriate background information. KIR reviewed and edited the revised versions of the submission, obtained consent from the patient's family and photographed the patient.

Funding The authors have not declared a specific grant for this research from any funding agency in the public, commercial or not-for-profit sectors.

Competing interests None declared.

Patient consent for publication Parental/guardian consent obtained.

Provenance and peer review Not commissioned; externally peer reviewed.

\section{REFERENCES}

1 Marghoob AA, Dusza S, Oliveria S, et al. Number of satellite nevi as a correlate for neurocutaneous melanocytosis in patients with large congenital melanocytic nevi. Arch Dermatol 2004;140:171.

2 Hayashi M, Maeda M, Maji T, et al. Diffuse leptomeningeal hyperintensity on fluidattenuated inversion recovery MR images in neurocutaneous melanosis. AJNR Am J Neuroradiol 2004;25:138-41.

3 Smith $A B$, Rushing EJ, Smirniotopoulos JG. Pigmented lesions of the central nervous system: radiologic-pathologic correlation. Radiographics 2009;29:1503-24.

Copyright 2019 BMJ Publishing Group. All rights reserved. For permission to reuse any of this content visit

https://www.bmj.com/company/products-services/rights-and-licensing/permissions/

BMJ Case Report Fellows may re-use this article for personal use and teaching without any further permission.

Become a Fellow of BMJ Case Reports today and you can:

- Submit as many cases as you like

- Enjoy fast sympathetic peer review and rapid publication of accepted articles

- Access all the published articles

- Re-use any of the published material for personal use and teaching without further permission

\section{Customer Service}

If you have any further queries about your subscription, please contact our customer services team on +44 (0) 2071111105 or via email at support@bmj.com.

Visit casereports.bmj.com for more articles like this and to become a Fellow 